\title{
THE ROLE OF PERCEIVED PARENTING STYLES IN RISK BEHAVIOR AMONG 10 TO 16 YEAR-OLD STUDENTS
}

\section{[ROZDIELY V RIZIKOVOM SPRAVANI ZIAKOV VO VEKU 10-16 ROKOV VZHLADOM NA PERCIPOVANY VYCHOVNY STYL]}

\author{
Robert Tomsik - Marcela Veresova
}

doi: 10.18355/PG.2019.8.1.10

\begin{abstract}
The main objective of the study is to identify the differences in risk behavior in relation to the perceived pupils' parenting styles. A Risk behavior questionnaire, consisting of six subscales, was used to examine individual forms of risk behavior, while a standardized DZSVR questionnaire was used to examine parenting styles. The research sample consists of pupils of elementary schools in all regions of the Slovak Republic, specifically 988 pupils aged between 10 and 16 years old. In the research, differences in risk behaviors were identified with regard to perceived parenting style. The results show that the highest mean scores of all forms of risk behaviors are shown by pupils who have been raised with autocratic and indifferent parenting styles, while the least endangered group is pupils who were raised with social-integrative parenting style.
\end{abstract}

Key words

Parenting styles, risk behavior, family, education, puberty

\section{Anotácia}

Hlavným ciel'om práce je identifikovat' rozdiely v miere rizikového správania vzhl'adom na percipované výchovné štýly žiakov. Pri skúmaní jednotlivých foriem rizikového správania bol použitý Dotazník rizikového správania pozostávajúci zo šiestich subškál, kým na zistenie výchovných štýlov bol použitý štandardizovaný Dotazník na zist'ovanie spôsobov výchovy v rodine. Výskumná vzorka bola tvorená žiakmi základných škôl všetkých krajov Slovenskej republiky. Išlo konkrétne o 988 žiakov vo veku od 10 až 16 rokov. Prostredníctvom výskumu boli zistené rozdiely v rizikovom správaní vzhl'adom na percipovaný výchovný štýl. Výsledky poukazujú, že najvyššiu mieru všetkých foriem rizikového správania vykazujú žiaci, ktorí boli vychovávaní autokratickým a indiferentným výchovným štýlom, kým najmenej ohrozenou skupinou sú žiaci, ktorí boli vychovávaní sociálnointegračným výchovným štýlom.

\section{Kl'účové slová}

Rizikové správanie, rodina, štýly výchovy, puberta, adolescencia, dospievanie 


\section{Teoretické a empirické východiská}

Puberta a adolescencia sú fázy v individuálnom živote človeka, ktoré sa spájajú s najväčším tlakom a dynamikou zmien, pričom obe fázy sú postupným prechodom $\mathrm{z}$ detstva do dospelosti, charakterizované fyzickým dozrievaním, výrazným kognitívnym a emocionálnym zrením, psychosociálnou štrukturáciou osobnosti, konfrontáciou so súborom spoločenských a iných životných nárokov a zároveň pretrvávajúcim obmedzeným prístupom $\mathrm{k}$ osobnej autonómii, ekonomickej nezávislosti, neobmedzenej slobode či sexuálnej slobode. Ceresnik (2016) v zmysle všetkých dynamických zmien odohrávajúcich sa počas dospievania (predstavujúce približne 10 rokov ontogenézy) konštatuje existenciu boja chladného (kognitívneho) a horúceho (afektívneho systému) v tomto období života človeka. V americkom prístupe (Institute of Medicine and National Research Council, 2011) je dospievanie/adolescencia vymedzené/á vekom od 10-19 rokov, zatial' napríklad Vagnerova (2000) preferuje členenie dospievania na pubertu (11-14 rokov) a adolescenciu (15-21 rokov).

Viacerí autori (napríklad Jessor, 1991; Arnett, 2000; Veresova, 2004; Ballocchini, E., Chiamenti, G., Lamborghini, 2013) konštatujú, že z pohl'adu výskytu a prejavov rizikového správania sú najrizikovejší adolescenti v porovnaní s mladšími alebo staršími vekovými skupinami.

Rizikové správanie/problémové správanie pubescentov a adolescentov zahrňuje zneužívanie návykových látok/závislostné správanie, rizikové sexuálne správanie, agresívne správanie, násilie a zranenia, šikanu, školskú neúspešnost'/zlyhanie a odchod zo školy, delikventné správanie a kriminalitu, nevhodné stravovacie návyky a nedostatočné pohybové aktivity/fyzickú nečinnost' (Jessor, 1991; Arnett, 2000; Veresova, 2004; Newman et al., 2008; Ceresnik, 2016). Podla zistení, najčastejším rizikovým správaním $\mathrm{v}$ adolescencii je rizikové sexuálne správanie, násilie, nehody a užívanie drog (Ballocchini, Chiamenti, Lamborghini, 2013).

Rizikové správanie adolescentov je funkčné, inštrumentálne a vedome zamerané na ciel' (Jessor, 1991). V adolescencii, ako aj puberte, slúži rizikové správanie aj ako nástroj prijatia a akceptácie zo strany rovesníckej skupiny (Jessor, 1991; Veresova, 2004), ktorá je vysoko významná v procese skupinovej socializácie, typickej a vysoko významnej pre tieto fázy vývinu. Na druhej strane, rizikové správanie limituje protektívny vývinový rozvoj efektívnych copingových stratégií a sociálnych zručností adolescentov (Jessor, 1991).

V kontexte behaviorálneho prístupu je rizikové správanie spájané $\mathrm{s}$ rozhodovacím procesom smerom $\mathrm{k}$ identifikácii a hodnoteniu potenciálnych výsledkov a dôsledkov správania dospievajúcich. Dospievajúci riskujú nie preto, že robia nesprávne rozhodnutia, ale preto, že hodnotia dôsledky svojho správania odlišne od dospelých (Lightfoot, 1997; in Savi-Çakar, Tagay, Ikiz, 2015). Dospievajúci si uvedomujú negatívne dôsledky rizikového správania, ale riskujú, pretože cielene chcú výsledok/uspokojit' potreby viac než dospelí (Romer, 2003; in Savi-Çakar, Tagay, Ikiz, 2015).

U rizikových l'udí podla Ceresnika a Ceresnikovej (2016) možno predpokladat' nízku mieru stimulácie zo strany rodičov (resp. zodpovedných osôb). Pravdepodobne boli vystavení málopodnetnému prostrediu, ktoré 
nevytváralo primerané podnety na psychomotorický a psychosociálny rozvoj. Samozrejme s ohl'adom na nárast elektronizácie a sociálneho bezkontaktného siet’ovania možno súhlasit' $\mathrm{s}$ autormi, že aj prebytok niektorých, pre dozrievajúci organizmus nepotrebných podnetov, pôsobiacich prostredníctvom televízneho prijímača či iných médií, je detský mozog prestimulovaný (overstimulating), čo spôsobuje neúmerné zvyšovanie jeho aktivačnej úrovne, ktorá sa prejaví vyhl'adávaním vzrušujúcich podnetov, či rizika.

Rodinné prostredie významne ovplyvňuje vývin diet’ata a dospievajúceho, na čom sa zhodujú odborníci z rôznych odvetví pedagogických, spoločenských a behaviorálnych vied. Ceresnik (2016) za rizikové faktory rodinného prostredia považuje stratu $\mathrm{v}$ rodine, dlhodobý konflikt, chronické choroby rodičov, nedostatočnú komunikáciu, dysfunkčnost’ rodiny, nízky alebo vel’mi vysoký socio-ekonomický status, autoritatívny výchovný prístup rodičov alebo benevolentný výchovný prístup a rozpory medzi hodnotami. Newman et al. (2008) publikovali analýzu existujúcich poznatkov ohl'adne vplyvu výchovy v rodine na rizikové správanie diet’ata/dospievajúceho a konštatujú významné prepojenie ukazovatel'ov rodinného prostredia na rizikové správanie: rodičovské teplo verzus chlad, prijatie verzus odmietnutie, štruktúra verzus chaos, autonómia verzus kontrola, angažovanost' verzus odlúčenie alebo zanedbávanie, prísnost' verzus tolerancia, konzistentná verzus nekonzistentná disciplína, blízkost' verzus vzdialenost', d’alej disciplína (konzistentná verzus nekonzistentná), úroveň rodičovskej angažovanosti, úroveň rodičovského monitorovania, spôsob komunikácie s diet’at’om a štýl výchovy. V našej výskumnej štúdii venujeme pozornost' práve poslednej $\mathrm{z}$ uvedených charakteristík rodinného prostredia, ktoré popisujú Newman et al. (2008).

Balasz a Piko (2012) definujú štýl výchovy ako interakciu medzi rodičom a diet’at’om/dospievajúcim v rámci obrovského množstva situácií nezávislých na správaní rodičov, pričom interakcia by mala zahŕňat' lásku, vrelost', kontrolu, autoritu, podporu a komunikáciu. Všetky uvedené činitele majú značný vplyv na vývin diet'at'a a formovanie jeho osobnosti, pričom autori vymedzujú dve základné dimenzie rodičovského výchovného štýlu vnímavost' (rodičovská vrelost', prijatie, premýšl'avost', zapojenie) a náročnost' (kontrola, monitoring, prísnost'). Pre zdravý vývin diet'at'a sa ako najkladnejšie uvádzajú výchovné štýly demokratický, resp. autoritatívny. Ako nevhodné štýly pre vývin dietata Langmeier, Krejcirova a Crhakova (2013) uvádzajú nasledovné výchovné štýly: rozmaznávajúca výchova, zavrhujúca výchova, nadmerne ochranárska výchova (hyperprotektívna), perfekcionistická výchova, nedôsledná výchova, zanedbávajúca výchova. Ďalším z často citovaných klasifikácií výchovných postojov rodičov je model Schaeffera (Schaeffer, Bell, 1958), v ktorom sa vzájomne hodnotia dve navzájom nezávislé a odlišné dimenzie: láska - nepriatel'stvo a autonómia kontrola, na základe ktorých možno e výchovné postoje rodičov $\mathrm{k}$ det’om zmysluplne opísat $\mathrm{v}$ troch faktorových dimenziách (Crhakova, 2013; Schaeffer, Bell, 1958): prijatie - odmietanie, psychologická kontrola psychologická autonómia, prísna kontrola - vol’ná autonómia. Podobný model ako vypracoval Schaeffer (Schaeffer, Bell, 1958) uvádzajú aj Cap a 
Boschek (1994). Ich model spôsobov výchovy je založený na zist'ovaní miery kladných a záporných komponentov výchovy, komponentov požiadaviek a vol'nosti. z ktorých je možné odvodit' štyri základné výchovné štýly v rodine: autokratívny, sociálno-integračný, indiferentný a liberálny. Kombinovaním emočného vzt’ahu rodičov a výchovného riadenia v rodine vzniká väčší počet rôznych štýlov výchovy $\mathrm{v}$ rodine, ktoré sú podl'a doterajších skúseností usporiadané do deviatich základných polí/ výchovných štýlov: záporný emočný vzt’ah a silné alebo stredné výchovné konanie, záporný emočný vzt’ah a slabé výchovné riadenie, záporný emočný vzt’ah a rozporné výchovné riadenie, kladný alebo extrémne kladný emočný vzt’ah a silné výchovné riadenie, kladný alebo extrémne kladný emočný vzt'ah a stredné výchovné riadenie, kladný emočný vzt'ah a slabé výchovné riadenie, kladný alebo extrémne kladný emočný vztah a rozporné výchovné riadenie, extrémne kladný emočný vzt’ah a slabé výchovné riadenie, záporne-kladný emočný vzt’ah a silné/stredné/rozporné výchovné konania (emočne rozporná výchova). Prepojenie deviatich polí podl'a Capa a Boscheka (1994) na redukované 4 výchovné spôsoby v rodine zobrazuje Tabul'ka 1 (Mayerova, 2013).

Tabul'ka 1: Model spôsobov výchovy (Mayerová, K., 2013)

\begin{tabular}{|c|c|c|c|c|}
\hline Výchovné riadenie & \multirow{2}{*}{ Silné } & \multirow{2}{*}{ Stredné } & \multirow{2}{*}{ Slabé } & \multirow{2}{*}{ Rozporné } \\
\hline Emočný vzt’ah & & & & \\
\hline Záporný & \multicolumn{2}{|c|}{ 1. Autokratická výchova } & $\begin{array}{l}\text { 2. Liberálna } \\
\text { výchova }\end{array}$ & $\begin{array}{l}\text { 3. Indiferentná } \\
\text { výchova }\end{array}$ \\
\hline Záporne-kladný & \multicolumn{4}{|c|}{ 9. Indiferentná výchova } \\
\hline \multirow[b]{2}{*}{ Extrémne kladný } & \multirow[b]{2}{*}{$\begin{array}{l}\text { 4. Indiferentná } \\
\text { výchova }\end{array}$} & \multirow{2}{*}{$\begin{array}{l}\text { 5. Sociálno- } \\
\text { integračná } \\
\text { výchova }\end{array}$} & $\begin{array}{l}\text { 6. Liberálna } \\
\text { výchova }\end{array}$ & \multirow{2}{*}{$\begin{array}{l}\text { 7. Indiferentn } \\
\text { výchova }\end{array}$} \\
\hline & & & $\begin{array}{l}\text { 8. Sociálno- } \\
\text { integračná } \\
\text { výchova }\end{array}$ & \\
\hline
\end{tabular}

Hoci existuje vel’a d’alších klasifikácií výchovných štýlov a je pomerne náročné vybrat' a identifikovat' najvhodnejšiu klasifikáciu pre výskumné účely, ked’že sa tieto štýly kombinujú a prelínajú. V našom výskume sme vybrali klasifikáciu výchovných štýlov podl’a Capa a Boscheka (1994) $\mathrm{z}$ viacerých dôvodov: model uvedených výchovných štýlov je založený na najčastejšie uvádzaných teoretických východiskách, ktoré triede štýly výchovy na štvordimenzionálny model; vychádza zo najuznávanejšieho modelu od Schaeffera (Schaeffer, Bell, 1958); je založený na zistovaní miery niekol'kých faktorov výchovy v rodne.

Predpokladáme existenciu rozdielov v rizikovom správaní dospievajúcich vo veku 10-16 rokov vzhl'adom na výchovný štýl v rodine (na základe predchádzajúcich štúdií, napr. Newman et al., 2008) pričom očakávame najvyššie zastúpenie rizikovosti u dospievajúcich vychovávaných autokratickým výchovným štýlom. Taktiež predpokladáme, že absencia 
kladného vzt'ahu s rodičmi a dennej interakcie s rodičmi bude najrizikovejšia u dospievajúcich vychovávaných autokratickým štýlom.

\section{Metodológia výskumu}

\subsection{Výskumná vzorka}

Výskumnú vzorku tvorilo 986 dospievajúcich priemerného veku 12,75 roka (štandardná odchýlka 1,483). Podiel chlapcov a dievčat bol 470 : 500 (41 neuviedlo údaj o pohlaví). Výskum bol realizovaný vo všetkých regiónoch Slovenska. Výber vzorky možno označit' za stratifikovaný. Sú v nej školy všetkých krajov Slovenskej republiky, školy vo vel'kých aj menších obciach/mestách.

Základný súbor výskumu tvorili žiaci/žiačky 5. až 9. ročníkov základných škôl. Celkový počet žiakov/žiačok v 5. až 9. ročníku základných škôl bol 203 172. To predstavuje vel'kost' základného súboru. Výskumný súbor je netriedený, tzn. že sme $\mathrm{z}$ neho nevyčlenili deti $\mathrm{s}$ individuálnym výchovnovzdelávacím plánom, resp. so špeciálnymi výchovno-vzdelávacími potrebami.

\subsection{Metódy}

Pri realizácii výskumu boli použité dva dotazníky na zistenie miery jednotlivých premenných: Dotazník na zist'ovanie štýlov výchovy v rodine a Dotazník rizikového správania. Autormi dotazníka DZSVR sú Cap a Boschek (1994). V dotazníku deti a mladiství vypovedajú o správaní svojich rodičov, o matke a otcovi zvlášt', v najobvyklejších situáciách. Dotazník bol od začiatku sedemdesiatych rokov postupne upravovaný na základe získaných výsledkov a skúseností tak, aby umožňoval syntetický pohl'ad na rodinnú výchovu. $\mathrm{V}$ súčasnej podobe má dotazník 80 položiek, desat' pre každý zo štyroch komponentov výchovy. Dotazník obsahuje komponent kladný, záporný, komponent požiadaviek a vol'nosti, ktoré zodpovedajú rodičovským postojom (podl'a Schudermannových škál a Schaefferovho dotazníka CRPBI a ADOR): pozitívny, hostílny, direktívny a autonómny. Položky sú administrované zvlášt' pre matku a otca a odpovede je možné zaznamenat' na trojbodovej škále: áno, čiastočne, nie. Kombináciou jednotlivých komponentov výchovy je možné vystihnút' emočný vzt'ah rodičov k diet'at'u a výchovné riadenie $\mathrm{v}$ rodine (komponenty výchovy) a následne celkový spôsob rodinnej výchovy (Cap, Boschek, P., 1994; Mayerova, 2013). Pomocou dotazníka je možné, na základe miery jednotlivých komponentov, zistit' devät' výchovných štýlov (uvedené v teoretických a empirických východiskách), ktoré je možne kumulovat' do štyroch základných, všeobecne uznávaných, výchovných štýlov: autokratický, sociálno-integračný (demokratický), liberálny a indiferentný (nevyhranený). Cronbachovho alfa jednotlivých subškál sa pohybuje od 0,59 až 0,82 . Vo výskumoch realizovaných pomocou tohto dotazníka rodinnej výchovy boli opakovane zistené štatisticky významné vzt’ahy medzi údajmi tohto dotazníka s d'alšími osobnostnými dotazníkmi, čo je ukazovatel’om empirickej validity (Cap, Boschek, 1994; Mayerova, 2013). 
Dotazník rizikového správania (DRS) pochádza z roku 2015, bol kreovaný a overený Ceresnikom. V tomto výskume bola použitá modifikovaná 38položková verzia. Participujúce/participujúce si vyberali z troch až ôsmich možností odpovede - vždy vo vzt'ahu k obsahu položky. Dotazník je vnútorne štruktúrovaný do 6 subškál:

A. Rodina a denné rituály (RDR) zahŕňa položky vztahujúce ku každodenným aktivitám rodiny a hodnoteniu vzt'ahu s rodičmi. Možné bodové rozpätie $\mathrm{v}$ tejto subškále je 0 až 15 bodov.

B. Škola a kamarátstva (ŠKK) zahíňa položky orientované na hodnotenie vzt’ahu k škole a spolužiačkam/spolužiakom. Možné bodové rozpätie v tejto subškále je 0 až 9 bodov.

C. Závislostné správanie (ZSP) zahíňa položky o uživaní najčastejšie sa vyskytujúcich psychoaktívnych látok. Možné bodové rozpätie v tejto subškále je 0 až 38 bodov.

D. Delikventné správanie (DSP) zahíňa položky o problematickom správaní súvisiacom s ničením cudzieho majetku a rešpektovaním autority. Možné bodové rozpätie v tejto subškále je 0 až 32 bodov.

E. Šikanovanie (ŠIK) zahŕňa položky orientované na vnímanie seba ako obete šikanovania. Možné bodové rozpätie v tejto subškále je 0 až 16 bodov.

F. Nevhodné stravovacie návyky a pohybové aktivity (NSP) zahŕňa položky o pasívnom trávení vol’ného času a nevhodných vzorcoch stravovania. Možné bodové rozpätie $\mathrm{v}$ tejto subškále je 0 až 27 bodov.

156 Úlohou participantov/participantiek bolo vybrat' si z troch až ôsmich možností odpovede - vždy vo vzt’ahu k obsahu položky.

\section{3 Štatistické spracovanie}

Pri štatistickom spracovaní dát boli použité štatistické programy IBM SPSS 20 (Statistical Package For The Social Sciences) a STATA 13. Na opis výskumných dát boli použité metódy deskriptívnej štatistiky (počet, priemer, štandardná odchýlka, štandardná chyba priemeru, minimum, maximum, šikmost' a špicatost'; Tomsik, 2017). Normalita distribúcie dát výskumného súboru bola zistovaná pomocou Kolmogorovovho-Smirnovovho testu normality, na základe ktorého bola potvrdená nesymetrickost' dát (vo všetkých premenných $\mathrm{p}<0,001)$ a pre d’alšie analýzy bol volený neparametrický test, konkrétne Kruskalov-Walisov H test. Pre tvorbu grafu boli hrubé skóre z Dotazníka rizikového správania transformované na Zskóre.

\section{Výsledky}

Pri posudzovaní výchovných štýlov, v porovnaní so štandardizovanými hodnotami, ktoré uvádzajú Cap a Boschek (1994) v príručke, bolo rozdelenie jednotlivcov podl’a výchovných štýlov podobné, avšak evidujeme určité rozdiely v distribúcii jednotlivcov vzhl'adom na percipované výchovné štýly. Autori uvádzajú, že autokratickým výchovným štýlom bolo vychovávaných $18,5 \%$ jednotlivcov, liberálnym $14,0 \%$, sociálno-integračným $24,0 \%$ a 
indiferentným $44,0 \%$. V porovnaní so štandardizovanými hodnotami, ktoré uvádzajú autori (Cap, Boschek, 1994), bol v našej vzorke výrazne väčší počet jednotlivcov vychovávaných indiferentným výchovným štýlom $(57 \%)$ a liberálnym výchovným štýlom $(20 \%)$. Kým pomer žiakov, ktorí boli vychovávaní autokratickým (12\%) a sociálno-integračným výchovným štýlom $(11 \%)$ je menší, v porovnaní so štandardizovanými hodnotami. V tabul'ke 2 sú uvedené zistenia o miere jednotlivých foriem rizikového správania. Vyššie priemerné skóre $(\mathrm{M})$ vyjadruje vyššiu mieru rizikového správania a ich foriem. Vzhl'adom na rozptyl, miery priemerných skóre jednotlivých premenných považujeme za nízke. Tieto zistenie korešpondujú aj so zisteniami štúdií s podobným dizajnom a výskumným zámerom (napr. Lepik, 2010; Sujit, 2006; Zemanova, Dolejs, 2015).

Tabul'ka 2: Deskriptívna štatistika výskumných premenných

\begin{tabular}{|c|c|c|c|c|c|c|c|c|}
\hline Premenná & $\mathbf{N}$ & $\mathbf{M}$ & SD & SEM & MIN & MAX & $\gamma \mathbf{1}$ & $\boldsymbol{\gamma} \mathbf{2}$ \\
\hline Rodina a denné rituály & 947 & 4,68 & 2,915 & 0,095 & 0 & 15 & 0,508 & 0,055 \\
\hline Škola a kamarátstva & 988 & 3,75 & 1,541 & 0,049 & 0 & 9 & 0,156 & 0,222 \\
\hline Závislostné správanie & 923 & 6,59 & 4,545 & 0,150 & 0 & 33 & 1,538 & 3,161 \\
\hline Delikventné správanie & 986 & 3,50 & 3,968 & 0,126 & 0 & 27 & 1,982 & 5,422 \\
\hline $\begin{array}{c}\text { Šikanovanie } \\
\text { Nevhodné stravovacie } \\
\text { naktivity }\end{array}$ & 971 & 4,26 & 4,809 & 0,154 & 0 & 25 & 1,483 & 1,874 \\
\hline $\begin{array}{c}\text { Rizikové správanie ÚS } \\
\text { Riknybove }\end{array}$ & 795 & 31,41 & 14,063 & 0,499 & 4 & 94 & 1,006 & 1,582 \\
\hline
\end{tabular}

*Pozn.: $N$ - počet; $M$ - priemer; SD - štandardná odchýlka; SEM štandardná chyba priemeru; MIN- minimum, MAX-maximum; $\gamma 1$ - šikmost; $\gamma 2-\check{s}$ picatost ${ }^{\prime}$

Pri komparácii premenných Dotazník rizikového správania a jeho celkového skóre vzhl'adom na percipovaný výchovný štýl u respondentov, boli zistené štatisticky významné rozdiely na hladine $\mathrm{p}<0,001$. Konkrétne, $\mathrm{v}$ premenných rodina a denné rituály, závislostné správanie, delikventné správanie, šikanovanie a rizikové správanie (celkové skóre) získali respondenti, ktorí boli vychovávaní autokratickým a indiferentným výchovným štýlom, signifikantne vyššie priemerné skóre $\mathrm{v}$ porovnaní $\mathrm{s}$ ostatnými výskumnými skupinami, kým respondenti, ktorí boli vychovávaní sociálno-integračným výchovným štýlom získali najnižšie priemerné skóre. Podobné výsledky, avšak $\mathrm{s}$ výrazne menším rozdielom $\mathrm{v}$ priemeroch boli zistenie aj $\mathrm{v}$ premennej škola a kamarátstva. V premennej nevhodné stravovacie návyky a pohybové aktivity získali respondenti, ktorí boli vychovávaní autokratickým a liberálnym výchovným štýlom, signifikantne vyššie priemerné skóre v porovnaní s ostatnými výskumnými skupinami, kým respondenti, ktorí boli vychovávaní sociálno-integračným výchovným štýlom získali aj v tejto 
premennej najnižšie priemerné skóre. Výsledky sú uvedené v tabul'ke 3 a sú graficky znázornené v grafe 1 .

Tabul'ka 3: Komparácia foriem rizikového správania vzhl'adom na percipovaný výchovný štýl

\begin{tabular}{|c|c|c|c|c|c|c|c|c|}
\hline $\begin{array}{l}\text { Rizikové } \\
\text { správanie }\end{array}$ & Štýl výchovy & $\mathrm{N}$ & M & SD & SEM & $\mathrm{df}$ & $\mathrm{H}$ & $\mathrm{p}$ \\
\hline \multirow{4}{*}{$\begin{array}{c}\text { Rodina a } \\
\text { denné rituály }\end{array}$} & $\begin{array}{l}\text { Sociálno- } \\
\text { integračný }\end{array}$ & 66 & 2,92 & 2,048 & 0,252 & \multirow{4}{*}{3} & \multirow{4}{*}{41,979} & \multirow{4}{*}{$<0,001$} \\
\hline & Liberálna & 119 & 4,24 & 2,527 & 0,232 & & & \\
\hline & Autokratická & 67 & 5,40 & 3,335 & 0,407 & & & \\
\hline & Indiferentná & 338 & 5,21 & 2,897 & 0,158 & & & \\
\hline \multirow{4}{*}{$\begin{array}{c}\text { Škola a } \\
\text { kamarátstva }\end{array}$} & $\begin{array}{l}\text { Sociálno- } \\
\text { integračný }\end{array}$ & 68 & 3,07 & 1,353 & 0,164 & \multirow{4}{*}{3} & \multirow{4}{*}{15,847} & \multirow{4}{*}{$<0,001$} \\
\hline & Liberálna & 116 & 3,49 & 1,405 & 0,130 & & & \\
\hline & Autokratická & 68 & 3,72 & 1,37 & 0,166 & & & \\
\hline & Indiferentná & 343 & 3,86 & 1,599 & 0,086 & & & \\
\hline \multirow{4}{*}{$\begin{array}{c}\text { Závislostné } \\
\text { správanie }\end{array}$} & $\begin{array}{l}\text { Sociálno- } \\
\text { integračný }\end{array}$ & 61 & 4,82 & 2,636 & 0,338 & \multirow{4}{*}{3} & \multirow{4}{*}{15,160} & \multirow{4}{*}{$<0,001$} \\
\hline & Liberálna & 115 & 6,63 & 4,057 & 0,378 & & & \\
\hline & Autokratická & 68 & 7,03 & 5,169 & 0,627 & & & \\
\hline & Indiferentná & 329 & 7,12 & 4,593 & 0,253 & & & \\
\hline \multirow{4}{*}{$\begin{array}{c}\text { Delikventné } \\
\text { správanie }\end{array}$} & $\begin{array}{l}\text { Sociálno- } \\
\text { integračný }\end{array}$ & 68 & 1,87 & 2,272 & 0,276 & \multirow{4}{*}{3} & \multirow{4}{*}{39,106} & \multirow{4}{*}{$<0,001$} \\
\hline & Liberálna & 121 & 2,52 & 2,864 & 0,260 & & & \\
\hline & Autokratická & 68 & 4,74 & 5,045 & 0,612 & & & \\
\hline & Indiferentná & 343 & 4,25 & 4,304 & 0,232 & & & \\
\hline \multirow{4}{*}{ Šikanovanie } & $\begin{array}{l}\text { Sociálno- } \\
\text { integračný }\end{array}$ & 66 & 1,85 & 2,942 & 0,362 & \multirow{4}{*}{3} & \multirow{4}{*}{43,331} & \multirow{4}{*}{$<0,001$} \\
\hline & Liberálna & 118 & 3,03 & 3,706 & 0,341 & & & \\
\hline & Autokratická & 66 & 5,94 & 5,92 & 0,729 & & & \\
\hline & Indiferentná & 339 & 4,77 & 5,117 & 0,278 & & & \\
\hline \multirow{4}{*}{$\begin{array}{c}\text { Nevhodné } \\
\text { stravovacie } \\
\text { návyky a } \\
\text { pohybové } \\
\text { aktivity }\end{array}$} & $\begin{array}{l}\text { Sociálno- } \\
\text { integračný }\end{array}$ & 66 & 7,20 & 3,245 & 0,399 & \multirow{4}{*}{3} & \multirow{4}{*}{23,494} & \multirow{4}{*}{$<0,001$} \\
\hline & Liberálna & 116 & 9,54 & 3,726 & 0,346 & & & \\
\hline & Autokratická & 69 & 8,97 & 3,502 & 0,422 & & & \\
\hline & Indiferentná & 335 & 9,44 & 3,656 & 0,2 & & & \\
\hline \multirow{4}{*}{$\begin{array}{c}\text { Rizikové } \\
\text { správanie } \\
\text { CS }\end{array}$} & $\begin{array}{l}\text { Sociálno- } \\
\text { integračný }\end{array}$ & 58 & 22,02 & 8,393 & 1,102 & \multirow{4}{*}{3} & \multirow{4}{*}{51,064} & \multirow{4}{*}{$<0,001$} \\
\hline & Liberálna & 101 & 29,54 & 11,904 & 1,185 & & & \\
\hline & Autokratická & 59 & 33,98 & 14,277 & 1,859 & & & \\
\hline & Indiferentná & 303 & 34,44 & 14,228 & 0,817 & & & \\
\hline
\end{tabular}

$N$ - počet; $M$ - priemer; SD - štandardná odchýlka; SEM - štandardná chyba priemeru; df-stupne vol'nosti; H- Kruskalov-Walisov H test; $p$ hladina štatistickej významnosti. 


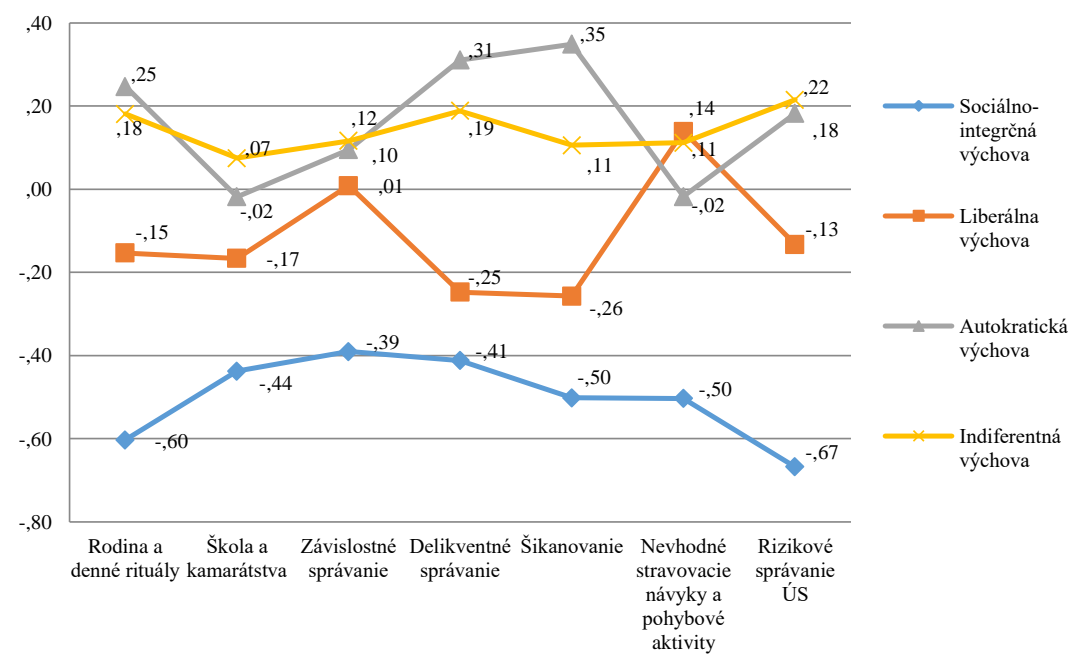

Graf 1: Komparácia foriem rizikového správania vzhl'adom na percipovaný výchovný štýl žiakov vo veku 10 do 16 rokov.

\section{Diskusia a záver}

$\mathrm{Na}$ základe našich výskumných zistení konštatujeme $\mathrm{v}$ súlade so syntézou zistení Newman et al. (2008), že existujú rozdiely v zastúpení rizikového správania dospievajúcich vo veku 10-16 rokov, ktorí sú vychovávaní rozdielnymi výchovnými štýlmi (autokratívny, indiferentný, liberálny, sociálno-integračný). Potvrdili sme náš predpoklad, že najrizikovejšie sa správajú dospievajúci vychovávaní autokratickým výchovným prístupom. V celkovom skóre rizikovosti najvyššie skórovali pubescenti a adolescenti vychovávaní autokratickou výchovou, hoci skóre rizikovosti dospievajúcich vychovávaných indiferentnou prístupom nie je významne nižšie a približuje sa tejto úrovni.

Zastúpenie autokratického výchovného štýlu rodičov $\mathrm{v}$ našom súbore dosiahlo $12 \%$, pričom takto percipovaný výchovný prístup je charakterizovaný záporným emočným vztahom a silným alebo stredným výchovným riadením rodičov. Prístup rodičov je centrovaný prevažne na negatívne hodnotenie diet’ata/ dospievajúceho, ktorý je často kritizovaný, sú u neho zdôrazňované nedostatky, podceňované schopnosti a kompetencie dospievajúceho, a to všetko pri vysokých nárokoch kladených zo strany rodiča na diet’a/dospievajúceho. $\mathrm{V}$ takejto rodine je dobrý výkon považovaný za samozrejmost'. Často sú aplikované aj tresty, absentuje podpora, pochvala a uznanie. Dospievajúci vychovávaný takýmto výchovným prístupom dosiahli najvyššie skóre rizikovosti $\mathrm{v}$ dvoch druhoch rizikového správania, a to delikventnom správaní a šikanovaní. V závislostnom správaní je ich rizikovost' porovnatel'ná s rizikovost’ou dospievajúcich vychovávaných indiferentným výchovným štýlom, u ktorých sme zaznamenali mierne vyššiu rizikovost', avšak s nevýznamnou hodnotou rozdielu v porovnaní s rizikovostou u dospievajúcich vychovávaných autokratickým štýlom. 
V rizikovom správaní zastúpenom negatívnym vztahom ku škole/ školužiačkam/ spolužiakom sme zaznamenali najvyššiu rizikovost' u dospievajúcich vychovávaným jedným z prístupov rodičov reprezentujúcich indiferentnú výchovu. $\mathrm{V}$ tomto type výchovného prístupu bolo vychovávaných najviac dospievajúcich $\mathrm{z}$ nášho výskumného súboru 1016 ročných $(\mathrm{N}=339=57 \%)$. Indiferentný výchovný štýl dospievajúcich z nášho výskumného súboru je $\mathrm{v}$ kontexte nami využitej výskumnej metódy (Čáp, J., Boschek, P., 1994) charakterizovaný jednou z možností:

- záporným emočným vzt’ahom rodiča $\mathrm{k}$ dospievajúcemu a rozporným výchovným riadením, čo má za následok vel'kú mieru emočnej lability dospievajúceho. Táto forma výchovy a prístup rodičov $\mathrm{k}$ dospievajúcemu dezorganizuje správanie a prežívanie diet'at'a, príznačná je trvalá neistota dospievajúceho, ktorému spravidla $\mathrm{v}$ každej situácii nie je jednoznačne jasné, aká reakcia bude nasledovat' zo strany rodičov (l'ahostajnost', odmena, trest). Rodičia $\mathrm{v}$ rámci tohto prístupu $\mathrm{k}$ diet'at'u vyžadujú plnenie úloh, ale absentuje kontrola ich plnenia.

- kladným alebo extrémne kladným emočným vzt’ahom a silným výchovným riadením, čo sprevádza prísna, dôsledná ale láskavá výchova, ktorá sa vyznačuje vzájomnou dôverou. Rodičia predstavujú pre dospievajúceho autoritu. Požiadavky rodiča na diet’a, zákazy a nariadenia bývajú často vysoké, dospievajúci ich akceptuje, pretože má s rodičmi priaznivý vzt’ah.

- kladným alebo extrémne kladným emočným vzt’ahom a rozporným výchovným riadením, čo je spojením priaznivej emočnej klímy, priatel'ského vzt’ahu rodičov s prísnym výchovným štýlom s absenciou požiadaviek na diet’a. Tento výchovný štýl je autormi charakterizovaný ako „láskavá prísnost“".

- záporne-kladným emočným vzt’ahom a silným, stredným, slabým alebo rozporným výchovným riadením rodičov, kedy vzt’ahy rodičov $\mathrm{k}$ diet’at'u nekorešpondujú a diet’a/dospievajúci tým pádom vníma jedného rodiča ako odmietajúceho, kým s druhým vytvára koalíciu. Táto forma výchovy zvyšuje emočnú labilitu diet’at’a.

Špecifikom z pohladu analýzy jednotlivých druhov rizikového správania, kde najvyššie zastúpenie rizika v správaní nebolo u dospievajúcich vychovávaných autokratickým prístupom rodičov alebo indiferentným prístupom rodičov, sme identifikovali v prípade nevhodných stravovacích návykov a nedostatku pohybu/fyzickej aktivity, kde najvyššie priemerné skóre rizikovosti dosiahli dospievajúci, ktorí boli vychovávaní liberálnym štýlom ( $\mathrm{N}=115=20 \%$ dospievajúcich $\mathrm{z}$ nášho výskumného súboru). Tento výchovný prístup rodičov je zastúpený jednou z možností (Č́áp, J., Boschek, P., 1994):

- záporným emočným vztahom a slabým výchovným riadením rodičov s typickým nezáujmom a l’ahostajnost’ou voči diet’atu/dospievajúcemu. Rodičov nezaujímajú potreby diet'at’a a nie sú ochotní byt' mu oporou či pomáhat' mu, dištancujú sa od diet’ata. Na diet’a sú kladené minimálne požiadavky, pričom rodičia majú pochybnosti o schopnostiach diet’at’a/dospievajúceho. 
- kladným emočným vzt’ahom a slabým výchovným riadením bez nárokov a požiadaviek, resp. len s minimálnymi požiadavkami na dospievajúceho a bez kontroly plnenia aj tých minimálnych požiadaviek. Charakteristický býva kamarátsky vzt’ah rodiča s diet’at’om, rodičia často „odstraňujúu diet’at’u všetky prekážky a rozmaznávajú ho.

Taktiež sme očakávali, že v nami realizovanom výskume potvrdíme, že absencia kladného vzt’ahu s rodičmi a dennej interakcie s rodičmi bude najrizikovejšia u dospievajúcich vychovávaných autokratickým štýlom. Uvedený predpoklad sme potvrdili. Značne vysoko rizikovo skórovali aj dospievajúcich vychovávaný indiferentným prístupom rodičov.

Vo všetkých rizikových formách správania najmenej rizikovo skórovali dospievajúci vychovávaní sociálno-integračným výchovným štýlom, ktorý je zastúpený jednou z možností (Čáp, J., Boschek, P., 1994):

- kladným alebo extrémne kladným emočným vzt’ahom a stredným výchovným riadením spájaným aj s vnímaním demokratickej výchovy. Pre tento prístup je charakteristický partnerský, rovnocenný vzt’ah diet’at'a a rodičov, deti/dospievajúci považujú rodičov za autority a ich požiadavky rešpektujú.

- extrémne kladným emočným vzt’ahom a slabým výchovným riadením. Pre tento výchovný štýl je charakteristický priatel'ský až kamarátsky vzt'ah detí s rodičmi, pričom diet’a/dospievajúci plní požiadavky rodičov z vlastnej iniciatívy a nie je kontrolované zo strany rodičov.

U tejto skupiny dospievajúcich vychovávaných sociálno-integračným prístupom rodičov sa potvrdil aj najmenej rizikový vzt’ah s rodičmi a zároveň existencia denného kontaktu s rodičmi. Uvedený výchovný prístup má protektívny charakter z pohladu rozvoja prejavov rizikového správania ako celku, resp. vo všetkých nami sledovaných druhoch.

Uvedomujeme si, že naša výskumná štúdia má aj svoje limity. Jedným je nerovnomerné zastúpenie dospievajúcich $\mathrm{v}$ kontexte sledovaných výchovných štýlov. Ďalším z limitov, ktorý zároveň vytvára aj priestor pre d’alší výskum a analýzu, je ten, ktorý by umožňoval jemnejšiu analýzu nie len z pohl'adu 4 štýlov výchovy ale aj jednotlivých polí emočného vzt’ahu rodičov a výchovného riadenia $\mathrm{v}$ rodine, čím vzniká väčší počet rôznych výchovných prístupov, ktoré sa kumulujú do nami sledovaných výchovných štýlov. Ďalším limitom je fakt, že sme nesledovali celé obdobie dospievania, ale sme centrovali pozornost' na dospievajúcich vo veku 10-16 rokov. Napriek uvedeným limitom sme presvedčení, že nami realizovaný výskum a uvádzané teoretické východiská majú prínos tak pre pedagogický ako aj psychologický rozmer poznania rozdielov v rizikovom správaní s ohl'adom na rodinné prostredie, konkrétne výchovné prístupy rodičov.

Paper is published within the frame of the project Vega 1/0122/17 Risk behavior and attachment of the adolescents aged from 10 to 15 . 


\section{Bibliographic references}

ARNETT, J. J. 2000. Emerging adulthood: A theory of development from the late teens through the twenties. American Psychologist, vol. 55, no. 5, pp. 469-480.

BALASZ, M. A. - PIKO, B. F. 2012. Control or involvement? Relationship between authoritative parenting style and adolescent depressive symptomatology. European Child \& Adolescence Psychiatry, vol. 21, pp. 21492155.

BALLOCCHINI, E. - CHIAMENTI, G. - LAMBORGHINI, A. 2013. Adolescents: which risks for their life and health? Journal of Preventive Medicine and Hygiene, vol. 54, no. 4, pp. 191-194.

CAP, J. - BOSCHEK, P. 1994. Dotaznik pro zjistovani spusobu vychovy v rodine. Prirucka. Bratislava: Psychodiagnostika, s. r. o., 100 p.

CERESNIK, M. 2016. Hranicna zona. Rizikove spravanie v dospievani. Nitra: UKF, $180 \mathrm{p}$.

CERESNIK, M. - CERESNIKOVA, M. 2016. Specifika rizikoveho spravania dospievajucich vo veku 10 az 15 rokov ohrozenych socialnou exkluziou. In E. Maierova, L. Viktorova, M. Dolejs (Eds.), PhD Existence VI. Vyzkum vs. prax: Cesko-slovensko psychologicka konference (nejen) pro doktorandy a o doktorandech. Olomouc : UP v Olomouci, pp. 275-282.

CRHAKOVA, I. 2013. Soucasna komunikace $v$ rodine a vychovne styly rodicu z pohledu zaku II. stupne zakladnich skol. Brno: MU, $84 \mathrm{p}$.

INSTITUTE OF MEDICINE AND NATIONAL RESEARCH COUNCIL.

2011. The Science of Adolescent Risk-Taking: Workshop Report. Washington, DC: The National Academies Press. doi.org/10.17226/12961.

JESSOR, R. 1991. Risk behavior in adolescence: A psychosocial framework for understanding and action. Journal of Adolescent Health, vol. 12, no. 8, 597-605.

LANGMEIER, J. - KREJCIROVA, D. 2007. Vyvojova psychologie. Praha: Grada Publishning.

LEPIK, F. a kol. 2010. Skolni dotaznikova studie o navykovych latkach, dalsich formach rizikoveho chovani a pilotni studie o uzivani tikavych lstek na zakladnich skolach praktickych: Karlovarsky kraj. Tisnov: SCAN.

MAYEROVA, K. 2013. Rodina vychova a motivacia ako cinitele uspesnosti adolescenta $\mathrm{v}$ kontexte celozivotneho vzdelavania. In E. Lukac (Ed.), Metamorfozy edukacie I. Katedra andragogiky. Presov: FHPV PU, 2013, 144 p.

NEWMAN, K. - HARRISON, L. - DASHIFF, C. - DAVIES, S. 2008. Relationships between parenting styles and risk behaviors in adolescent health: an integrative literature review. Revista Latino-Americana de Enfermagem, vol. 16, no. 1, p. 142-150.

SAVI-CAKAR, F. - TAGAY, O. - IKIZ, F. E. 2015. Risky Behaviors of Adolescents: Definitions and Prevention. In A. M. Columbus (Ed.), Advances in Psychology Research. Volume 106, Nova Science Publishers.

SCHAEFER E. S. - BELL, R. Q. 1958. Development of a Parental Attitude Research Instrument. Child Development, vol. 29, no. 3, pp. 339-361.

SUJIT, S. et al. 2006. Prevalence of conduct disorder in school children of Kanke. Indian Journal of Psychiatry, vol. 48, no. 3, p. 154-169. 
TOMSIK, R. 2017. Kvantitativny vyskum v pedagogickych vedach. Uvod do metodologie a statistickeho spracovania. Nitra: PF UKF, 505 p.

VAGNEROVA, M. 2000. Vyvojova psychologie. Praha: Portal, 522 p.

VERESOVA, M. 2004. Mediatory uzivania drog: cesta k efektivnej prevencii drogovych zavislosti. Nitra: UKF, $394 \mathrm{p}$.

ZEMANOVA, V. - DOLEJS, M. 2015. Zivotni spokojenost, sebehodnocenia vyskyt rizikoveho chovani u klientu NZDM. Olomouc: Univerzita Palackeho.

PaedDr. Robert Tomšik, PhD.

Department of Educational and School Psychology

University of Constantinus the Philosopher in Nitra

Tr. A. Hlinku 1, 949 74, Nitra

Slovakia

rtomsik@ukf.sk

doc. PaedDr. Marcela Verešová, $\mathrm{PhD}$.

Department of Educational and School Psychology

University of Constantinus the Philosopher in Nitra

Tr. A. Hlinku 1, 949 74, Nitra

Slovakia

mveresova@ukf.sk 